\title{
The Influence of Activity-Based Teaching Method Used in Teaching Social Studies on Students Retention and Academic Performance: A Quasi-Experimental Study of Selected Junior High School Students in Sekyere South District of Ashanti Region, Ghana
}

\author{
Thomas Sarpong1, Francis Atta Sarpong ${ }^{\circledR}{ }^{\circledR}$, Angelina Osei Asor ${ }^{1}$ \\ ${ }^{1}$ Department of Social Science, Atebubu College of Education, Atebubu, Ghana \\ ${ }^{2}$ School of Economics and Management, Anhui University of Science and Technology, Huainan, China \\ Email: brefosarpongthomas@gmail.com,francis.sarpong@stu.ucc.edu.gh/nanaipee@gmail.com, asorosei@yahoo.com
}

How to cite this paper: Sarpong, T., Sarpong, F. A., \& Asor, A. O. (2020). The Influence of Activity-Based Teaching Method Used in Teaching Social Studies on Students Retention and Academic Performance: A Quasi-Experimental Study of Selected Junior High School Students in Sekyere South District of Ashanti Region, Ghana. Open Journal of Social Sciences, 8 , 238-254.

https://doi.org/10.4236/jss.2020.812018

Received: November 20, 2020

Accepted: December 19, 2020

Published: December 22, 2020

Copyright ( 2020 by author(s) and Scientific Research Publishing Inc. This work is licensed under the Creative Commons Attribution International License (CC BY 4.0).

http://creativecommons.org/licenses/by/4.0/ (c) (i) Open Access

\begin{abstract}
The focus of teaching methods in Ghana now has been teaching that allows the interest and needs of students to be the center of teaching and learning. One of the popular teaching methods which makes this basic aim of education possible to reach in this modern era is the use of activity-based teaching method. The paper is thrust on investigating the impact of activity-based teaching method used in teaching social studies on students' retention and academic performance within the Sekyere South District of Ashanti Region. The study adopted the quasi-experimental research design, using both questionnaire and 40-multiple choice tests items in its investigation. The study found that activity-based teaching method was beneficial to students learning social studies in junior high school in many ways. They include: students develop high-order thinking skills, retain social studies' concepts more easily, become active in class, interests are sustained, maximize potential in performing well in class. The study further found that activity-based teaching strategies such as collaborative learning, problem-solving learning and co-operative learning positively significantly affect students' retention in social studies. The study again found that there is a significant difference between the academic performance of experimental and control groups.
\end{abstract}

\section{Keywords}

Activity-Based Teaching, Students' Retention, Academic Performance Social 
Studies

\section{Contextualization of the Study}

In the economic development of any nation, education of its citizenry has been the bedrock of national development since it helps in equipping students with the requisite knowledge, attitude, competencies, and skills useful for the nation as a whole in terms of employment opportunities for the youth and a substantial impact on the society (Anwer, 2019; Okoro, 2019). By adopting the right curriculum, Ghana has ensured transformation in addressing issues and problems that face the country. The curriculum implemented can be effective in achieving its purpose only through adequate planning and execution of the curriculum by the teachers of such curriculum (Anwukah, 2000). Curriculum such as social studies has been designed purposely as an instrument that can be used for a social, economic, and political revolution to draw attention to national issues and moral self-indulgence in the economy (Okoro, 2005).

Social studies' knowledge must be imparted to students in the most inventive way to help students develop thought-provoking thinking skills (Iwuamadi, 2013). The question that comes to mind now is how effective and efficient the teaching and learning process, depends on the teaching methodology adopted in teaching social studies concepts (Dike, 2002). A review of the literature indicated that some social studies teachers prefer the traditional expository (lecture) (Onwukwe, 2010; Abimbade \& Afolabi, 2012) teaching method; others prefer the problem solving-based teaching method (Meziebo, 2005). The lecture method is a teacher-centered method which involves the teacher just talking and writing about social studies concepts on the board for students. In contrast, the problem-solving approach consists of the teacher assigning students with social problems to find answers to which in the long run creates a student-friendly environment that involves using students' own imaginative thinking skills, brainstorming, discussion, role-playing to find the solution to problems. Mezieobi (2005) defined activity-based teaching method as one that entails sparkling students' involvement in developing intelligent and self -reliant students.

The National Knowledge Commission (NKC, 2009) posits that the activity-based teaching method used in teaching social studies provided students with the hope of solving practical problems using their resources. Studies have shown that students taught through the activity-based approach can retain the subject much longer than those taught without (Özen \& Ergenekon, 2011). Several researchers (Shah \& Rahat, 2014; Bansal \& Kumar, 2012; Choo, 2007) have highlighted the enormous benefits of using activity-based teaching methods in teaching subject matter of social studies. The services posited include; activity-based teaching helps students achieve desired goals set by teachers for concepts learned in social studies, encourages students to learn independently, and motivates them to learn to foster higher-order skills and creative thinking. 
Recently, with the rampant increase in crime waves in Africa where Ghana is part and the rise of other societal cankers, some researchers have alluded that this might be due to poor teaching and learning of Social Studies in schools. A question pops up in mind: are social studies teachers effective in teaching the right knowledge, attitude, competence, and skills? Could it be that the methods used in its teaching and learning are not effective in teaching the appropriate expertise, philosophy, and skills to the learners, or could it be that teachers of Social Studies are still using the conventional methods, like a lecture and other teacher-centered strategies in the teaching of Social Studies or could it be that teachers are not familiar with or trained to use some of the identified activity-based strategy as stated in the background to the study? This might be a result of the teaching method adopted in teaching students. This is because the level of retention in social studies concepts actually impart how students attach seriousness in studying the subject matter. Students being taught with practical examples of real-life issues and how social studies can help in resolving such issues will determine if students benefit from such subject matter in and out of the classroom. According to Curriculum Research Development Division (2010), the curriculum and social studies were designed to develop students with moral obligations, patriotic citizens and enlighten society's youth about social cankers such as crime, conflict, drug abuse, religious strife, etc. more. All these objectives can be attained with the help of the teachers of social studies. The activity-based teaching method is regarded as the somewhat rarely used method by Ghanaian teachers to foster students' understanding of social studies. As a result of this backdrop, the study sought to investigate the influence of activity-based teaching methods in teaching social studies lessons on Junior high school students' retention and academic performance.

\section{Purpose of the Study}

This study's main thrust was to investigate activity-based teaching's influence in teaching social classes on students' retention level and academic performance. To fulfill this aim, the study sought to specifically:

1) Find out the benefits Junior High School students (experimental and control group) derived from teachers' use of activity-based teaching methods in teaching social studies.

2) Examine the significant effect of activity-based teaching methods on Junior High School students' (experimental and control group) retention level of social studies concepts.

3) Determine the significant difference between control and experimental group of students on the impact of activity-based teaching methods on students' academic performance.

\section{Emerging Issues in Literature}

The traditional lecture method has been liberated in educational institutions un- 
til the recent introduction of activity-based teaching methods to actively engage students with various teaching curricula, such as social studies (Yamarik, 2007). The activity-based teaching method is the method that enables students to learn subject matter with the same robustness that marks their biological activity (Inekwe, 2002). The major teaching strategies associated with activity methods are discussion, simulation, collaborative, field trips, project, debate, demonstration, dramatization, questioning, and role-playing. These methods entail active and lively involvement and participation of Social Studies learners. Various researcher such as (Kaka, 2007; Felder \& Brent, 2005) opined that activity-based teaching method reduces abstract teaching of social studies concepts, encourages student's involvement in the learning of the subject matter, admiring the uniqueness of their colleague's response to social problems and promotes self-thinking of students. Ahlfeldt, Mehta, and Sellnow (2005) posited in their research into the benefits of the use of activity-based teaching method in teaching that this method ensures a good relationship between teachers and students, ensures active learning of the subject matter, harmony between students and teachers and also encourages prompt feedback from teachers to students.

Researchers such as (Petress, 2008; McGrath \& MacEwan, 2011) revealed that students become more actively involved in teaching and learning and therefore can understand various concepts in subject matters such as social studies when taught with the activity-based teaching method. They further indicated that students are taught real-life issues, provided with practical and meaningful lesson which in the long boost the social awareness of students to social concepts and phenomenon. Sun and Zhang (2007) revealed that activity-based teaching method motivates students to adapt creatively to change. Students taught with an activity-based approach can take charge of externally driven change, rather than being controlled by it, which has been shown to distinguish schools that are more effective and more rapidly improving from those that are not. In Ghana, social studies teachers must understand the relevance of the activity-based teaching method since it ensures a better understanding of social studies concepts. Many developing countries, including Ghana, require enormous input in the educational sector as it lacks basic teaching strategies. The training of teachers will add to the information for student learning (Bichi, 2002). By providing training, teachers will be more capable of incorporating improvement on an individual and community level. Thus, it will help improve the motivational attributes and enhance critical thinking skills and creativity of the teachers and the students.

On the subject of how the use of activity-based teaching method helps in boosting the retention level of students, Khan et al. (2012) found that students can retain information more easily when the teacher uses discussion in the classroom, students' interest is sustained when the lesson is taught using the activity-based method. They further found that the activity-based teaching method ensures the development of students' higher-order skills and maximizes stu- 
dents' retention capacity. Similar studies on activity-based teaching methods impact students' retention level revealed that activity-based teaching methods ensure students' higher academic achievement (David, 2007). This implies that students have higher retention levels when taught with activity-based teaching methods than other methods. Mahapatra (2009) reported that an activity-based learning strategy increased students' cumulative achievements. This study's finding is also in agreement with Khan, Muhammad, Ahmed, Saeed and Aman (2012), who reported that activity-based learning strategy significantly improved students' academic performance than the prevalent traditional or expository teaching method. They recommended that activity-based teaching strategies should be used to teach students that are developing higher-order skills to maximize the benefits of these approaches. Activity learning strategy appears to be getting greater acceptance as a method of teaching Social Studies. This might be due to the reported advantages it offers, such as providing the learners with an in-depth knowledge of subject matter content; it develops learners' interest and leads to discovering new facts. Some of the activity-based strategies include; collaborative, co-operative, and problem-solving techniques.

\subsection{Effective Learning Framework}

The study adopted a framework to highlight how using a particular teaching method can affect students in terms of their retention level, satisfaction in the classroom, and motivation to develop a self-learning spirit (Boettcher, 2007). This can only occur if teachers in the school create a positive learning environment using activity-based strategies that enhance students' learning. All educational stakeholders play a critical role in ensuring that teachers are up to the task and actively involve students in teaching and learning. This can only be possible when a positive understanding is created for students to think within and outside the classroom and be conversant with social studies concepts (Shuaibu, 2005; Paterson, Jackson, \& Grieve (2012). Learning can be effective if it gives students a chance to be motivated to use their brains to solve social problems. It is flexible enough to support the diverse learning abilities of students in the classroom. Figure 1 briefly explains how effective learning should be at the school and that society also plays a part in ensuring that students can think critically and creatively in the community.

The Influence of activity-based teaching method used in teaching social studies on students' retention and academic performance.

\subsection{Research Hypothesis}

1) $H_{1}$ : Junior High School students (experimental and control group) derive benefits from teachers' use of activity-based teaching methods in teaching social studies.

2) $\mathrm{H}_{2}$ : There is a significant effect of teachers' use of activity-based teaching methods on students' retentions in social studies concepts. 


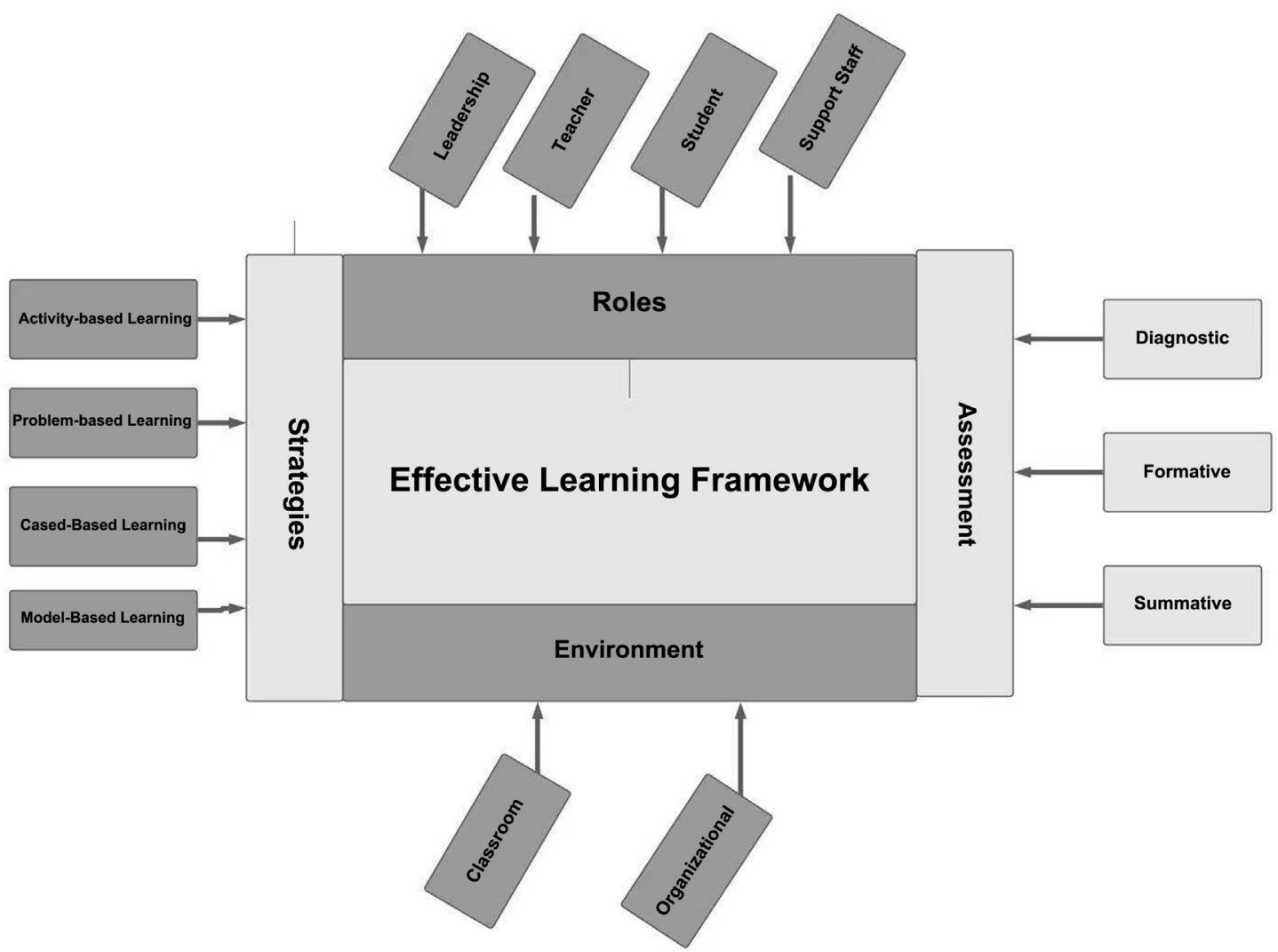

Figure 1. Effective learning framework. Source: Adopted from Patil, Budihal, Siddamal and Mudenagudi (2018).

3) $H_{3}$ : There is a significant difference between experimental and control groups of students on the impact of activity-based teaching methods on students' academic performance.

A literature review inspired the hypothesis that governs the study to investigate what other researchers have done regarding the topic under investigation.

\section{Research Model}

Based on the findings of the study and an extensive review of literature, a conceptual model was designed for the study. This conceptual model sought to establish how the use of activity-based teaching method in social studies benefits students in their academic pursuit, affect their retention level in social studies and the difference between experimental and control group academic performance in social studies. This was illustrated in Figure 2.

The study adopted the quasi-experimental study design. This involves the use of an experimental group and a controlled group (Fraenkel \& Wallen, 2012). Researchers taught students some concepts in social studies to the experimental group making use of activity-based teaching methods. In contrast, the control group was introduced to the same concepts without necessarily using activity-based teaching methods. Students were taught in a period of 180 minutes. Two respective days were used in teaching and preparing students for the test. A standardized 40 Multiple Choice Question (MCQ) was given to the control 


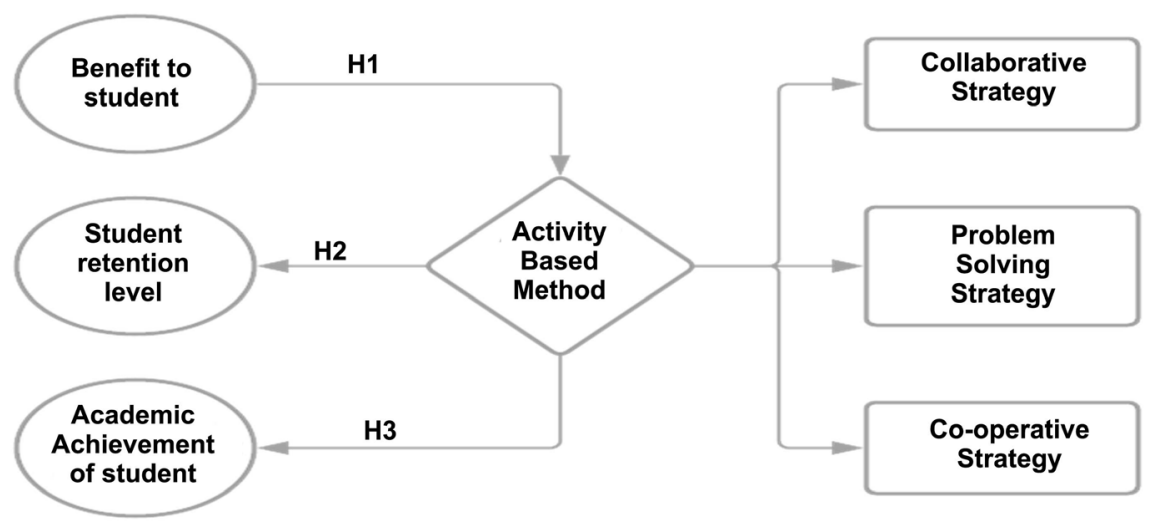

Figure 2. Conceptual model.

group. This was pre-tested and also post-tested (Fraenkel \& Wallen, 2012). In the Pre-test-Post-test Non-equivalent groups' design, a treatment group is given a pre-test, receives a treatment, and then is given a post-test. But at the same time, there is a non-equivalent control group given a pre-test, does not receive the treatment, and then is given a post-test. The 40-MCQs items had a test duration of 50 minutes for both categories of students to answer the questions under a supervised invigilation to ensure that there was no cheating during to test to ensure validity of the scores of students.

The population covered 700 junior high school (JHS) students studying Social Studies in Sekyere South District of Ashanti Region, Ghana. A sample size of 200 junior high (JHS) social studies students in three selected schools were purposively sampled. This was in line with recommendations by Gay and Diehl (1992) that a sample size of $10 \%-20 \%$ is appropriate for a study. Hence, the study used $28.6 \%$ of total respondents for the study. The stratified simple random sampling was adopted in selecting the 200 junior high school students from the three selected schools for the study. This sampling method was chosen for the study because it puts respondents into three stratums and randomly chooses students based on the total number of students in the school divided by the overall population of 700 and multiplied by the sample size of 200 . The 200 students randomly selected were divided into two equal-half where 100 students were in the control group and 100 in the experimental group without considering their respective schools. Three types of instruments were adopted for the study. Researchers first sought the overall academic performance of students in general to understand their retention level. Secondly, pre-test and post-test students assessed students and tested two achievement tests, consisting of multiple type questions, were developed. The instrument was validated by three experts in Curriculum Studies and Educational stakeholders relevant in social studies from Atebubu College of Education, Mampong Monica's College of Education, and Agona SDA College of Education. A reliability index of 0.89 was established for the survey using the Pearson product-moment correlation coefficient. Experts' opinion was taken for the reliability and validity of achievement test, and questionnaire handed over to students. 
A questionnaire was given to students to determine the benefits they perceived activity-based teaching methods could have on their retention level. The instrument was pilot-tested in Atebubu environs, and the alpha reliability of the test was computed at 0.93 . Finally, a post-teaching survey was conducted to analyse lessons taught to both experimental and controlled group students. The researcher taught both classes. Five chapters from education textbooks JHS were selected and taught through hands-on activities. The controlled group was introduced in the traditional way of instruction. The questionnaire and marked scores of students were analysed using the Statistical Product for Social Sciences (SPSS) version 25. The analysis was computed into (frequencies and percentages) for the demographic information. Descriptive statistics (mean and standard deviation) were calculated for research question one, multiple linear regression for research hypothesis two, and independent t-test for hypothesis three of the study.

\section{Sample Distribution of Respondents}

This section dealt with the information collected on the background of the respondents. The characteristics of the respondents discussed in this section include the gender and age, level of study of students. Table 1 presents the background information of the respondents.

Table 1 shows the demographic information of the Junior High School students involved in investigating activity-based teaching social studies on students' retention and academic achievement. Information sought from students on their background revealed that (128) $64 \%$ of the students involved in the study were males while (72) $36 \%$ were females. This proves that more males were involved in the study than female counterparts, as reflected in male and female students' bias in the Ghanaian education system. Table 1 shows that (35) $17.5 \%$ of the respondents were 11 years or below regarding students' age. The majority (125),

Table 1. Background information of respondents.

\begin{tabular}{cccc}
\hline Variable & Sub-scale & Frequency & Percentage \\
\hline Gender & Male & 128 & 64 \\
& Female & 72 & 36 \\
Age & Below 11 years & 35 & 17.5 \\
& $12-15$ years & 125 & 62.5 \\
& Above 15 years & 40 & 20 \\
Level of Study & Form One & 45 & 22.5 \\
& Form Two & 100 & 50 \\
& Form Three & 55 & 27.5 \\
Group of Students & Control group & 100 & 50 \\
& Experimental group & 100 & 50 \\
\hline
\end{tabular}

Source: Field data, 2019. 
representing $62.5 \%$ of the students, were between 12 - 15 years. A significant number (40) $20 \%$ of the students were above 15 years. The table further revealed that (45) $22.5 \%$ of the Junior High School students were in Form One and (55) $27.5 \%$ studying in form two. Majority of the participants were in the second year (Form Two) with a total of (100) $50 \%$ of total respondents. This indicates that most of the respondents were old enough to give adequate information regarding activity-based methods in teaching social studies at the junior high school level. In order to ensure equality and fairness for the study, an equal number of students were put into either the control group or experimental group. In addition, there was a fair representation of all three levels of students in Junior High school and hence, their ability to have an idea of how the use of activity-based teaching in social studies affects their academic performance and retention level.

\subsection{Main Results and Findings}

Research Hypothesis One: The use of activity-based teaching methods in teaching social studies is beneficial to junior high school students' academic excellence and moral values

The activity-based teaching method has a place in the teaching of social studies in these contemporary trends. An activity-based process will help students not have adequate social studies concepts and practice them in a real social environment. Research Hypothesis One sought to explore the benefits associated with the use of activity-based methods in ensuring higher academic excellence and moral values. The results are presented in Table 2.

Table 2 summarizes the benefits students derived from the use of activity-based teaching methods in teaching social studies. From Table 2, students

Table 2. Benefits of the use of activity-based teaching method in teaching social studies.

\begin{tabular}{|c|c|c|c|c|c|c|}
\hline & \multicolumn{2}{|c|}{ Post-test } & \multicolumn{2}{|c|}{ Pre-test } & \multirow{2}{*}{$\begin{array}{c}\text { Mean } \\
\text { Gain }\end{array}$} & \multirow{2}{*}{$\begin{array}{l}\text { Rank } \\
\text { Order }\end{array}$} \\
\hline & Mean & $\mathrm{SD}$ & Mean & $\mathrm{SD}$ & & \\
\hline Students' develop high order thinking skills & 4.59 & 0.63 & 4.20 & 1.06 & 0.39 & 1 \\
\hline Students' become an active in class & 4.42 & 0.84 & 3.91 & 1.18 & 0.51 & 2 \\
\hline Students' retain social studies concepts more easily & 4.36 & 0.87 & 3.90 & 1.19 & 0.46 & 3 \\
\hline Students' interest is sustained & 4.34 & 0.91 & 3.85 & 1.08 & 0.49 & 4 \\
\hline Students' performance in test increases & 3.98 & 0.88 & 3.80 & 1.12 & 0.18 & 5 \\
\hline Students' maximize their potentials & 3.97 & 0.97 & 3.59 & 1.27 & 0.38 & 6 \\
\hline Students become self-educators & 3.96 & 1.24 & 3.52 & 0.69 & 0.44 & 7 \\
\hline students more become open in the classroom & 3.78 & 1.31 & 3.22 & 0.77 & 0.56 & 8 \\
\hline Students' become efficient in making decisions & 3.71 & 1.27 & 3.17 & 0.96 & 0.54 & 9 \\
\hline Students with diverse needs are met & 3.23 & 1.07 & 3.16 & 1.04 & 0.07 & 10 \\
\hline Mean of means/Average Std. Dev. & 4.03 & 0.99 & 3.63 & 1.04 & 0.40 & \\
\hline
\end{tabular}

Source: Field data, 2019 Scale: Strongly Disagree (0.5 - 1.4), Disagree (1.5 - 2.4), Uncertain (2.5 - 3.4), Agree (3.5 - 4.4), Strongly Agree (4.4 - 5.0). 
Table 3. Model summary of overall regression analysis.

\begin{tabular}{|c|c|c|c|c|c|c|c|c|c|c|}
\hline \multirow{2}{*}{ Model } & \multirow{2}{*}{$\mathrm{R}$} & \multirow{2}{*}{ R Square } & \multirow{2}{*}{$\begin{array}{l}\text { Adjusted R } \\
\text { Square }\end{array}$} & \multirow{2}{*}{$\begin{array}{l}\text { Std. An error } \\
\text { of the Estimate }\end{array}$} & \multicolumn{5}{|c|}{ Change Statistics } & \multirow{2}{*}{ - Durbin-Watson } \\
\hline & & & & & R Square Change & F Change & df1 & df2 & Sig. F Change & \\
\hline 1 & $0.433^{\mathrm{a}}$ & 0.187 & 0.161 & 0.91459 & 0.187 & 7.000 & 3 & 91 & 0.000 & 2.305 \\
\hline
\end{tabular}

Source: Field data, 2019.

overwhelmingly consented to the statement reflecting the benefits they believe in deriving from their encounter with the use of activity-based teaching method by their teacher, and these were shown in their respective mean of means and average standard deviation of (Mean of means $=4.03$, Average Std Dev $=0.99$ ) for the experimental group and (Mean of means $=3.63$, Average Std Dev $=1.04$ ) for the control group. This indicates that the majority of students agreed to the statements in Table 3. There appears to be no significant difference between the means scores of pre-test and post-test. However, there was a mean gain by analyzing students' responses in the experimental group taught with an activity-based teaching method (Overall Mean gain $=0.40$ ). This means that students who received activity-based treatment appear to realize that this particular teaching method can affect them in a positive direction in terms of learning social studies issues and concepts.

The study found the stances of both experimental and control group of respondents on the benefits of activity-based method revealed that students strongly agreed $($ Mean $=4.59,4.42,4.36,3.98,3.97)$ for the experimental group of students, that they develop high order thinking skills, become an active participant, retain information more easily, interests are sustained and performance in test increases when the lesson is taught through the activity-based method. In the same vein, students in the control group also strongly agreed to these facts aforesaid with respective (Mean $=4.20,3.91,3.90,3.85$, and 3.80).

Research Hypothesis Two: Regression Analysis of the effect of the use of activity-based teaching method on students' retentions of social studies concepts

This section deals with the discussion of the results based on the data collected from the field. The data is used to answer the second research hypothesis that guided the study. Multiple linear regression analysis was executed to explore if relevant evidence was available to permit the researchers to decide whether there is a direct relationship amongst the dependent variable ( $Y$ ), Academic Achievement, as well as the independent variables(s), $X_{1}, X_{2}, \ldots X_{p-1}$ (Collaborative learning, Problem-solving learning, Co-operative learning). The findings of the study have been clearly stated in Tables 3-5.

Mathematically, the linear model is stated below as;

$$
\mathrm{SR}=\beta_{0}+\beta_{1} \mathrm{CL}+\beta_{2} \mathrm{PS}+\beta_{3} \mathrm{CoL}+\mathrm{E}
$$

where; SR = Students Retention level, $\mathrm{CL}=$ Collaborative Learning, PS = Problem-Solving Learning, $\mathrm{CoL}=\mathrm{Co}$-operative Learning. 
Table 4. Regression analysis model ANOVA.

\begin{tabular}{ccccccc}
\hline \multicolumn{2}{c}{ Model } & Sum of Squares & Df & Mean Square & F & Sig. \\
\hline & Regression & 17.565 & 3 & 5.855 & 7.000 & $0.000^{\mathrm{b}}$ \\
1 & Residual & 76.119 & 200 & 0.836 & & \\
& Total & 17.565 & 197 & & & \\
\hline
\end{tabular}

Source: Field data, 2019.

Table 5. Overall regression analysis model coefficient.

\begin{tabular}{|c|c|c|c|c|c|c|c|c|c|c|c|}
\hline & \multirow{2}{*}{ Model } & \multicolumn{2}{|c|}{$\begin{array}{l}\text { Unstandardized } \\
\text { Coefficients }\end{array}$} & \multirow{2}{*}{$\begin{array}{c}\text { Standardized } \\
\text { Coefficients } \\
\text { Beta }\end{array}$} & \multirow{2}{*}{$\mathrm{T}$} & \multirow{2}{*}{ Sig. } & \multicolumn{3}{|c|}{ Correlations } & \multicolumn{2}{|c|}{ Collinearity Statistics } \\
\hline & & B & Std. Error & & & & Zero-order & Partial & Part & Tolerance & VIF \\
\hline \multirow{4}{*}{1} & (Constant) & 2.282 & 0.450 & & 5.075 & 0.000 & & & & & \\
\hline & $\mathrm{CL}$ & 2.339 & 0.150 & 0.228 & 2.255 & 0.027 & 0.329 & 0.230 & 0.213 & 0.872 & 1.147 \\
\hline & PS & 2.323 & 0.125 & 0.281 & 2.592 & 0.011 & 0.371 & 0.262 & 0.245 & 0.757 & 1.320 \\
\hline & $\mathrm{CoL}$ & 2.029 & 0.088 & 0.035 & 0.329 & 0.043 & 0.224 & 0.034 & 0.031 & 0.781 & 1.280 \\
\hline
\end{tabular}

Source: Field data, 2019.

The $\beta_{0}, \beta_{1}, \beta_{2}$, and $\beta_{3}$ are unidentified or unfamiliar coefficients whose values are forecast by analysis of regression from the SPSS software. $\mathrm{E}$ is the unplanned (random) error term with an anticipated cost of zero and a variance of 1.

The direct association among the dependent variable is students' retention as a measure of activity-based teaching methods in teaching social studies. The independent variables are Collaborative, problem-solving, and co-operating teaching methods. This analysis is meant to establish the relationship between the various activity-based teaching methods employed in teaching social studies and students' retention level. The coefficient of determination $\left(\mathrm{R}^{2}\right)$ and correlation coefficient $(\mathrm{R})$ was used to show the degree of relationship between the independent variables as well as (dependent variable), as shown in Table 3. It was found that these independent variables (collaborative, problem-solving, and co-operative learning) significantly $(p=0.000)$ affect the dependent variable (students' retention level). Collaborative learning has a significant positive effect on students' retention level from the model. This means that an increase in any of these independent variables would increase students' retention level; thus, a $1 \%$ increase in each of these independent variables would affect students' retention level by the coefficient (2.339). In the same vein, problem-solving and co-operative learning appear to influence students' retention levels in social studies concepts significantly positively.

This means that an increase in problem-solving leaning by teaches and co-operative learning would lead to an increase in students' retention level; thus, a $1 \%$ increase in problem-solving and co-operative learning would increase students' retention level by the coefficient (2.323 and 2.029) respectively as shown in Table 4. The R square for Model from Table 3 shows that $43 \%$ of the varia- 
tion in students' retention in social studies concepts is affected by teachers' use of collaborative, problem-solving, and co-operative learning strategies. These are all activity-based teaching methods. This implies that the model SR $=2.282+$ $2.339 \mathrm{CL}+2.323 \mathrm{PS}+2.029 \mathrm{CoL}+\mathrm{E}$ is significant. The overall model summary confirms the objectives of this study that there is a positive connection among the independent variables as well as the dependent variable because the use of activity-based teaching method such as collaborative, problem-solving, and co-operative learning strategy by teachers can affect the ability of students to retain the social studies concepts they are taught in the classroom.

Research Hypothesis Three: the difference between experimental and control groups of respondents on the impact of activity-based teaching method on students' academic performance

This study's aspect sought to elicit from student academic performance in social studies whether activity-based teaching method affects it. The two groups of students were given 40 standardized multiple-choice items in social studies concepts to answer. The two groups' scores were put in the SPSS software to compute the difference in students' performance in the control and experimental group. Table 6 explains the difference between these two groups of students to establish whether activity-based teaching can affect students' academic performance or not. To address this research objective, the researchers computed an independent sample t-test. The results of the independent sample t-test are presented in Table 6.

Table 6 reveals that a significant difference exists between the control and experimental group of students in terms of their academic performance. The mean scores recorded for the control group $(M=32.75, S D=0.5 .51)$ and $(M=64.73$, $\mathrm{SD}=6.84$ indicate a significant difference between students' performance activity-based teaching method and those taught with the traditional teaching method in social studies. It can be inferred that experimental groups of students possess an adequate understanding of concepts taught in social studies than their counterparts.

It is empirically established that students exposed to activity-based teaching strategies have higher mean scores than their control group counterparts. From Table, that there is a significant difference in the academic performance of students taught with activity-based teaching method in social studies $(M=32.75$, $\mathrm{SD}=5.51$ for control group and $(\mathrm{M}=64.73, \mathrm{SD}=6.84$ for experimental group); $t(198)=1.54, \mathrm{~F}=3.909, p=0.021$ (two-tailed). This means there is a significant difference between the mean scores of the experimental (group) and the control

Table 6. Difference between academic performance of control and experimental group.

\begin{tabular}{cccccccc}
\hline Group & Mean score & SD & $T$ & Df & F & $P$ & Decision \\
\hline Control & 32.75 & 5.51 & 1.54 & 198 & 3.909 & 0.021 & significant \\
Experimental & 64.73 & 6.84 & & & & & \\
\hline
\end{tabular}

p $>0.05$ two-tailed; Source: Field Data, 2019. 
groups in favor of the experiential group. This implies that the experimental group that was taught social studies concepts using an Activity-Based teaching strategy achieved significantly positive academic performance than the control group that taught the same concepts using the other teaching methods. It is found that there the use of an activity-based teaching strategy is more effective than the conventional method of teaching social studies.

\subsection{Discussions}

In this study it was revealed that the use of activity-based teaching methods in teaching social studies facilitates and enhances learning students' learning of social studies concepts which are relevant to current situations and practical life. The use of activity-based teaching methods such as collaborative, problem-solving and co-operative learning positively directs students learning in maximizing their potential as responsible citizens of a Ghanaian society. The findings of the study are in line with the results of (Azuka, 2001; Esiobu \& Soyibo, 1995) that activity-based teaching can help develop students physically, psychologically, and academically by making students lively in class with sustained interest in class and social issues. These finding again was reechoed by (Modebelu \& Ogbonna, 2014; Khan, Muhammad, Ahmed, Saeed, \& Aman, 2012; Mahapatra, 2009) that the use of activity-based teaching better students' performance in any given subject. Such studies confirmed the findings of the study that activity-based teaching method strategy amplified students' collective academic achievements that students' performance improved over a period of time with a change in teaching method by teachers to activity-based methods. This further implied that activity-based teaching method in teaching students help develop students' higher-order thinking skills in social studies concepts.

Moreover, the study's findings pointed out that using an activity-based learning strategy in teaching social studies to students facilitated learning among respondents. This implies that collaborative, problem-based and co-operative activity-based teaching method were all effective in enhancing students' retention level and academic performance. The collaborative learning activity-based strategy was more operative than co-operative and problem-based learning among the three variables tested to determine how they affect students' retention level. In the same vein, the co-operative learning activity-based strategy was also found to have enhanced students' retention level and was more effective than problem-based. This finding is constructed with results of studies conducted by another researcher such as (Korthagen, \& Wubbels, 2001; Khan, et al., 2012), who found that activity-based strategy improves students' retention level that activity-based teaching method ensures the development of higher-order skills of students and that it maximizes students' retention capacity. Similar studies on activity-based teaching methods impact students' retention level revealed that activity-based teaching methods ensure students' higher academic achievement. This discovery of the study is treaty with the findings of (Anwer, 2019; Danjuma, 2015; Kegan, 1994; Korthagen \& Wubbels, 2001; Sofeme, 2012) that revealed that 
the use of activity-based teaching method such as collaborative learning, problem-based and co-operative approach amplifies students' academic achievement in any subject area. This is as results of the activeness of students and teachers in the teaching and learning of any subject matter such as social studies.

\section{Conclusion and Practical Implication of the Study}

The use of activity-based teaching methods in teaching social studies appears to be used effectively in imparting the content knowledge of social studies to students to become successful in their learning. Regarding the benefits of the activity-based method, it can be concluded that the use of activity-based teaching methods in social studies motivates students to be self-learners and improves performance. This is crucial since teachers' teaching styles in class in teaching social studies concepts attract students, play a positive role in their understanding level, and improve academic achievement for better learning results. An activity-based teaching method is needed in current knowledge where learners learn by practice and avoid rote memorization, which has been practiced in teaching social studies by some Ghana teachers. Therefore, teachers who teach their students with this method are preparing them to meet global demands and not bookish academic learning, which does not impact improvements in education and society. The study also found that there is a significant difference between the control and experimental group. It implies that Experimental Group students' performance showed notable improvement in social studies after undergoing activity-based teaching strategies such as collaborative, problem-solving, and co-operative learning. This indicates that teaching social lessons with activity-based methods has a philosophical influence on students' academic achievement.

This study's significance relates to the contribution of this present study to the body of literature on the impact of the use of activity-based teaching method on the teaching and learning of social studies and understanding and improving the use of activity-based education to enhance students learning. This study's findings would serve as reference documents for researchers and other academicians who wish to conduct further studies on using the activity-based method in teaching and learning social studies.

This study's results would be beneficial to ministry of education, students, teachers, and even heads of junior high schools in Ghana. The benefits of this educational stakeholder have been clearly listed below.

\section{Ghana Education Service}

The study offers findings and recommendations of this study can be implemented by the Ministry of Education and the Ghana Education Service in promoting the use of activity-based teaching method by social studies teachers in boosting student's retention level and academic achievement in social studies and even other subject area offered in students in Junior High School.

\section{Students}


The study 's findings can benefit students' by making them aware of how effective the use of activity-based teaching method can be so that they can pay due attention and become highly involved in teaching instructions in social studies so as to improve their self-learning skills and self-reliance.

\section{Teachers}

The findings of this study would enable social studies teachers to become aware of how they actively involve students in their teaching and learning by developing students' domain of learning such as cognitive, affective and psychomotor domains. Hence, motivate teachers to adopt activity-based teaching strategies that enhance students' self-esteem, spirit, and confidence. This study's findings would also go a long way in helping teachers use appropriate instructional techniques to improve students' performance and learning skills. In the long run, this will create a good school image since students will be satisfied to be in such a school

\section{Heads of Educational Institutions}

The study would also provide information to Educational administrators, planners, and headmasters of Junior high schools on the greater instructional strategies teachers can adopt to ensure greater effectiveness of the teaching and learning process. This will cause many heads of institutions to insist on encouraging teachers too often and if possible, use activity-based teaching method in teaching students at the junior high school level.

\section{Conflicts of Interest}

The authors declare no conflicts of interest regarding the publication of this paper.

\section{References}

Abimbade, A., \& Afolabi, S. S. (2012). A Study of Pedagogical Approaches of Mathematics Teaching in Southwestern States of Nigeria. International Journal of Asian Social Science, 100, 1182-1192.

Ahlfeldt, S., Mehta, S., \& Sellnow, T. (2005). Measurement and Analysis of Student Engagement in University Classes Where Varying Levels of PBL Methods of Instruction Are in Use. Higher Education Research and Development, 24, 5-20. https://doi.org/10.1080/0729436052000318541

Anwer, F. (2019). Activity-Based Teaching, Students' Motivation and Academic Achievement. Journal of Education and Educational Development, 6, 154-170. http://dx.doi.org/10.22555/joeed.v6i1.1782.g502

Anwuka, T.G. (2000). Curriculum Development for Responsive Education in Third World Countries. Owerri: Cape Publishers.

Azuka, B. F. (2001). Strategies for Effective Teaching of Mathematics Topics in Secondary Schools. A Paper Presented during Kogi State Mathematics Teachers Clinic and Workshop for the Improvement of the Teaching of Mathematics in Schools, Kabba, Nigeria.

Bansal, V., \& Kumar, R. (2012). Activity Based Learning New Method of Learning: A Case Study of Teach-Next. International Journal of Research in Economics and Social 
Sciences, 2, 414-428.

Bichi, S. S. (2002). Effects of Problem-Solving Strategy and Enriched Curriculum on Students' Achievement in Evolution Concepts Amongsecondary Students. Unpublished Ph.D. Dissertation, Zaria: Faculty of Education, Ahmadu Bello University.

Boettcher, J. V. (2007). Ten Core Principles for Designing Effective Learning Environments: Insights from Brain Research and Pedagogical Theory. Innovate, 3, 1333-1356.

Choo, C. B. (2007). Activity Based Approach to Authentic Learning in a Vocational Institute. Educational Media International, 44, 185-205. https://doi.org/10.1080/09523980701491633

Curriculum Research Development Division (CRDD) (2010). Social Studies Teaching Syllabus for Junior High Schools. Accra: Ministry of Education.

Danjuma, S. G. (2015). Problems Militating against the Teaching of Integrated Science and students' Achievement in Taraba State Junior Secondary School. Unpublished Master's Thesis, Abuja: National Open University of Nigeria.

David, S. O. (2007). Effects of Activity-Based Teaching Method on the Academic Achievement of Slow Learners in Chemistry at the Senior Secondary School Level. Unpublished Thesis, Zaria: Department of Education (Science) of the Faculty of Education, Ahmadu Bello University.

Dike, H. I. (2002). Alternative Teaching Approaches for Social Studies with Implications for Science and Social Studies. Port Harcourt: Capiic Publishers.

Esiobu, G. O. \& Soyibo, K. (1995). Effect of Concept and Vee Mapping under Three Learning Modes on Students' Cognitive Achievement in Ecology and Genetics. Journal of Research in Science Teaching, 32, 971-995. https://doi.org/10.1002/tea.3660320908

Felder, R. M., \& Brent, R. (2005). Understanding Students' Differences. Journal of Engineering Education, 94, 57-72. https://doi.org/10.1002/j.2168-9830.2005.tb00829.x

Fraenkel, J. R., \& Wallen, N. E. (2012). How to Design and Evaluate Research in Education (8th ed.). New York, NY: McGraw-Hill.

Gay, L. R., \& Diehl, P. L. (1992). Research Methods for Business and Management. In Hill, R. (1998) (Ed.), What Sample Size Is "Enough' in Internet Survey Research"? Interpersonal Computing and Technology: An Electronic Journal for the 21st Century. http://www.emoderators.com/ipct-j/1998/n3-4/hill.hmtl

Inekwe, I. O. (2002). Sensitizing Students Learning of Mathematics through Affective Means: A Focus on the Universal Basic Education. Nigeria Education Forum. A Journal of Institute of Education, Ahmadu Bello University, Zaria, 16, 76, 81.

Iwuamadi, F. N. (2013). Effective Teaching of Social Studies (A Contemporary Approach). Owerri: Clear Image Publishers.

Kaka, M. O. (2007). Games Assisted Instructional Materials-A Strategy for Enhancing Students' Achievement in Integrated Sciences. Journal of Research in Curriculum and Teaching, 2, 120-128.

Kegan, S. (1994). Cooperative Learning Method. New York: Kagan Publishing. http://www.keganonline.com

Khan, M., Muhammad, N., Ahmed, M., Saeed, F., \& Aman, K. S. (2012). Impact of Activity-Based Teaching on Students' Academic Achievements in Physics at Secondary Level. Academic Research International, 3, 146-156.

Korthagen, F. A. J., \& Wubbels, T. (2001). Learning from Practice. In F. A. J. Korthagen, J. Kessels, B. Koster, B. Lagerwerf, \& T. Wubbels (Eds.), Linking Practice and Theory (pp. 48-66). New York, NY: Routledge.

Mahapatra, A. (2009). Activity Based Learning Effectiveness of ABL under SSA. New 
York, NY: Prentice Hall.

McGrath, J. R., \& MacEwan, G. (2011). Linking Pedagogical Practices of Activity-Based Teaching. The International Journal of Interdisciplinary Social Sciences: Annual Review, 6, 261-274. https://doi.org/10.18848/1833-1882/CGP/v06i03/51803

Mezieobi, K. A. (2005). Social Studies in Nigeria Teaching Materials and Resources. Owerri: Acadapeak Publishers.

Modebelu, M. N., \& Ogbonna, C. C. (2014). Reform-Based Instructional Method and Learning Style on Students' Achievement and Retention in Mathematics: Administrative Implications. International Journal of Education and Literacy Studies, 2, 48-52. https://doi.org/10.7575/aiac.ijels.v.2n.2p.48

National Knowledge Commission (2009). Report to the Nation 2006-2009.

Okoro, C. O. (2005). Development and Validation of Extracurricular Instructional Package (EIP) in Social Studies. Unpublished PhD Thesis, Port Harcourt: University of Port Harcourt.

Okoro, C. O. (2019). Activity-Based Learning Strategies and Academic Achievement of Social Studies Students in Obio/Akpor Local Government Area. International Journal of Education and Evaluation, 5, 19-24.

Onwukwe, E. O. (2010). Combined Effects of Play-Simulations and Teaching with Analogy on Secondary School Students' Achievement in Chemistry. Ph.D. Dissertation, Awka: Nnamdi Azikiwe University.

Özen, A., \& Ergenekon, Y. (2011). Özel Eğitimde Etkinlik Temelli Öğretim Uygulamaları. Kuram ve Uygulamada Eğitim Bilimleri, 11, 351-362.

Paterson, A. S., Jackson, W. J., \& Grieve, A. P. (2012). The Enhancement of Generic Competencies through the Application of Student Centred Learning: The Students Perspective (No. 1201). Accountancy Research Group, Heriot Watt University.

Patil, U., Budihal, S. V., Siddamal, S. V., \& Mudenagudi, U. K. (2018). Activity Based Teaching Learning: An Experience. Journal of Engineering Education Transformations, 29, 2394-1707.

Petress, K. (2008). What Is Meant by Active Learning? Education, 128, 566-569.

Shah, I., \& Rahat, T. (2014). Effect of Activity Based Teaching Method in Science. The International Journal of Human Resource Management, 2, 39-41.

Shuaibu, A. A. M. (2005). Lecture Note EDSE 701 Foundation of Science Education. Zaria: Faculty of Education, Ahmadu Bello University.

Sofeme, R. J. (2012). Impact of Cooperative Learning Approach on Senior Secondary School Students' Performance in Mathematics. Ife Psychology IA, 20, 4.

Sun, P., \& Zhang, F. (2007). To Improve Teaching Effectiveness with Undergraduates' Taking Part in Scientific Research. Journal of Shenyang College of Education, 9, 57-58.

Yamarik, S. (2007). Does Cooperative Learning Improve Student Learning Outcomes? The Journal of Economic Education, 38, 259-277.

https://doi.org/10.3200/JECE.38.3.259-277 